の変化は Fig.3〜6の 1-C～7-C, 1a-C～7a-Cの曲線

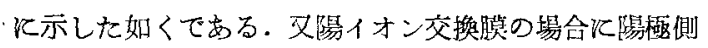
に脱塩水, 陰極側に $\mathrm{N} / 100 \mathrm{KCl}$ 液を入れ, 㓌イ才ン交 換膜ではこの逆に液を入れた場合の透析電流の变化を別 测定し，それぞれ同一膜についてとの方法による電流 に対する前に示した方法による電流の比を比較し，Fig． 3〜6の 1-R〜7-R 及び 1a-R〜7a-Rの曲線に示した.

これ等の曲線を比較すると強酸性カチオン交换膛及び 強盐基性アニオン交換膜は透析電流が時閒の経過と共に

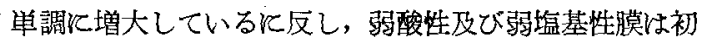
めは電流が増大するが整く電解すると雲流がや小減少す る傾向を示している.これはカルボン酸系の膜の場合電 解中 $\mathrm{KCl}$ 濃度が稀いため晹極側に $\mathrm{H}^{+}$濃度が增加しこ れが膜中に入り $\mathrm{K}^{+}$を交換するため，膜の電導度が著し く低下するためであると考えられる，又同様に弱垻基性 膜も除極室に生成した $\mathrm{OH}^{-}$が膜内の $\mathrm{Cl}^{-}$と交換し電導 度を低下させるためであるろと考えられる。

又透析電流の比恬いずれの膜も非常に小さく，圆定イ オンと同符号ィオンの通過に対しては著しい抵抗を示す ことが分る。

\section{5. 総 括}

イオン交換樹脂とポリ塩化ビニルの混合イオン交換膜 について $\mathrm{KCl}$ 溶液中の電気拴抗を測定し, 膜の電導度

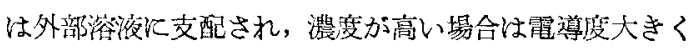
同一濃度の溶液中ではイオン交換樹脂含有率の大きい膜 が大きい. 膜の抵抗の減少のためにはアルコール処理に

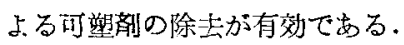

又よく水洗したイオン交換膜の電導度は，交換イオン によって暴り，交换活性基の性質及び濃度，並び膜内 の交換イオシの解離江支配されると考えられる。

更に透析電流関して実験を行い，これらの哯は電解 用として使用した場合にす優れた選択的イオン透過性を 示すことを知つた。 また弱酸文は強㬈基性膜の透析電流 の特異な性質は膜の $\mathrm{H}^{+}$又仡 $\mathrm{OH}^{-}$- 基の生成による電 導度の低下基く必のと考光られる。

本研究を行うに当り，イオン交換樹脂は日本才ルガノ 商会より提供を受けたるので, 社長丸山正武氏同研究所 長清水博士沉深謝の意を表ずる。

(明 $28-3-28$ 受理)

文献

(1) E. Heymann, I.J, O'Donnel : J. Colloid. Sci., 4, 405 (1949)

(2) W. Juda, W.A. McRae: J. A.C.S., 72, 1044 (1950) !W. Juda. N.W. Rosenberg, J.A. Marinsky, 体 1 名: ibid., 74, 3736(1952); J.T.C larke, J.A. Marinsky, W. Jnda, 他 2 名; J. Phys, Chem., 56,100 (1952)

(3) T.R.E. Kressman : Nature, 165568 (1950)

(4) G. Manecke, K.F. Bonhoeffer : Z. Elektrochem., 55, 475 (1951)

(5) K. Sollner, H.P. Gregor : I. Colloid Sci, , 7, 37, (1952)

\title{
工業用水の電解的脱珪 法
}

\author{
山村利夫 ·武貞䉆一 \\ （三菱化成工業黑崎工場）

\section{Removal of Soluble Silica from Water by Electrolytical Method} \\ Toshio YAMAMURA and Tokuichi TAKESADA \\ (Kurosaki Factory, Mitsubishi Chem. Ind. Ltd., Kurosaki)
}

The removal of soluble silica from boiler water is of importance to prevent the formations of silicate boiler scale and silicious deposits of turbine blade especially in the case of the high steam pressure turbine operation. Although some studies have been made on this problem, none of them seems to be satisfactory.

A new method, originally devised by Prof. Okamoto of Hokkaido University, has been studied and improved by the present authors, and turned out efficient and economical. In the new method, the feed water is electrolysed by aluminium plate electrodes between which a number of alminium sheets are inserted as bi-polar electrodes, electrolys- ing current being superposed by alternating current. Soluble silica in water is adsorbed by alminium hydroxide prepared electrolytically at the electrodes and is removed. The treated water contains soluble silica less than 1 p.p.m., where as the original water (Yawata city water) contains 18 p.p.m. of soluble silica.

Enlarging the treating capacity to $6-15$ tons of water per hour, the same result has been satisfactorily obtained.

In addition to the removal of silica, the process is also effective to decrease the hardness, turbidity, and iron and salts content of water.

(Received July 23, 1953) 


\section{1. 緒}

\section{言}

含有量飞変動はあるが，工業用水中には必ず珪酸の含 有を認める。この理酸がボイラー及びタービンのスケー ルとして沈着した場合それぞれ熱伝導を悪化し，発電効 率を低下寸ることは准々琶められる．X線回析法によつ た通常の，又は特殊のスケール成分の武験報告によれば， 珪酸の関与するボイラー・スケールの成分は次表の様に 特長づけられている.

\begin{tabular}{l|l}
\hline 名 & \multicolumn{1}{|c}{ 租成 } \\
\hline Acmite & $\mathrm{Na}_{2} \mathrm{O}, \mathrm{Fe}_{2} \mathrm{O}_{3}, 4 \mathrm{SiO}_{2}$ \\
Analcite & $\mathrm{Na}_{2} \mathrm{O}, \mathrm{Al}_{2} \mathrm{O}_{3}, 4 \mathrm{SiO}_{2} \cdot 2 \mathrm{H}_{2} \mathrm{O}$ \\
Cancrinite & $4 \mathrm{Na}_{2} \mathrm{O}, \mathrm{CaO}_{4}, 4 \mathrm{Al}_{2} \mathrm{O}_{3}, 2 \mathrm{CO}_{2}$, \\
Noselite & $9 \mathrm{SiO}_{2}, 3 \mathrm{H}_{2} \mathrm{O}$ \\
Pectolite & $\mathrm{Na}_{2} \mathrm{O}, 3 \mathrm{Al}_{2} \mathrm{O}_{3}, 6 \mathrm{SiO}_{2}, \mathrm{SO}_{4}$ \\
Serpentine & $\mathrm{Na}_{2} \mathrm{O}, 4 \mathrm{CaO}_{3} 6 \mathrm{SiO}_{2}, \mathrm{H}_{2} \mathrm{O}$ \\
Wollastonite & $3 \mathrm{MgO}, 2 \mathrm{SiO}_{2} \cdot 2 \mathrm{H}_{2} \mathrm{O}$ \\
Xonotlite & $\mathrm{CaSiO}$ \\
& $5 \mathrm{CaO}, 5 \mathrm{SiO}_{2}, \mathrm{H}_{2} \mathrm{O}$
\end{tabular}

これ等スケールを生成する成分の除去のうちで，理酸 の除去は他の成分例衤ば硬度成分等の除去飞比較して工 業的に実施することが困難であつて，現在迄工業的に実 施して特に効果的な方法の確立を見ていない ${ }^{(12)}$.

在来法(1) 脱珄法として在来から行われている方法 は專ら純化学的に製造された吸着性物質 (例总ば $\mathrm{Al}, \mathrm{Fe}$ $\mathrm{Mg}$ の水酸化物又は酸化物）の添加による吸着法によつ ている.

マグネシャを使用する高温法以外の方法は，何れる処 理中に溶解塩類の増加を来す欠点がある，即ち吸着削調 製時江副生する艺硝及び $\mathrm{pH}$ 調節郕の添加等沈よる塩類 増加忏避付られない，更に在来法では経済的脱珪の限界 か残留珠酸 $3 \sim 5 \mathrm{mg} / l$ 程度とされて括り(2) $1 \mathrm{mg} / l$ 以 下とするには吸着戍の多量を必要とする.

:イオン交換樹脂法：ポイラーが最近の様に高温高圧に 指向する傾向を取ると，必然的にその給水はイオン交換 樹脂で脱塩する必要が生してて来る．午水中に珠酸が蓄積 した場合高圧蒸気中に珪酸が出現する ${ }^{(3)(4)}$ ため，特に脱 珪する必要が生じて来る. 弗化物法 ${ }^{(2)(5)}$ Kよると弱塩基 性の陰イオン交換樹脂を用いて脱塩と同時に脱珃を行 ことも出夹るが，毎時 $20 \mathrm{t}$ の工業的規模て行つた試験 結果 ${ }^{(6)}$ 亿よれば，操作，調節が須雑で経済性は低い，又 強塩基生陰イオン交換樹脂汇よる脱珪は，モリブデン酸 アンモンによる普通の分析法では発色しない珪酸（コロ イド状珪酸と考える説もある）の除去に対してその効果

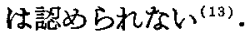

“電解脱珪法 : 水酸化アルミニウムを電解的炕製造し, これを以て脱理せんとする企図については既に一，二の 報告 ${ }^{(7)(8}$ があるが，去の詳細は不明であり，工業化生不
可能とされていたが北大工学部岡本教授等は基礎的飞詳 細保討してその可能性を䜅められた ${ }^{(14)}$. 筆者等は電解 脱珪法の試験を行い，水酸化アルミニウムの慜造条件及 びその脱理効果を検討した後, 工業的規模 $(15 \mathrm{t} / \mathrm{h}$ 処理) まで拡大して試験した結果工業化の可能性を見出した。

\section{2. 実 験 装 置}

交流重畳電解装置 ${ }^{(9)}$ 第 1 図の样に組立てた。

電極 : アルミニウム板 $(99.6 \%$ 純度) $85 \times 120 \times 3 \mathrm{~mm}$ 又は $80 \times 50 \times 3 \mathrm{~mm}$ 極間隔 : $10 \mathrm{~mm}$ 電解夜：主として八幖上水（分析結果後述）

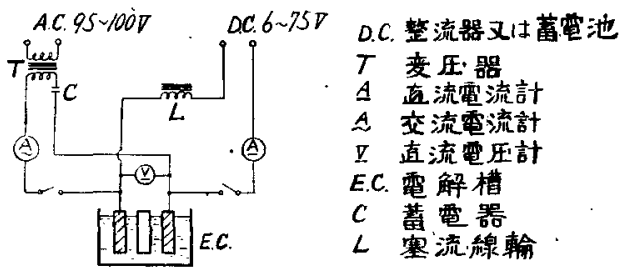

第 1 目 交直併用電解結線図

\section{3. 分 析 法}

（1）アルミニウムの測定法

(i) 重量法

(ii） 比色法 (ヘマトキシリン法) $)^{(10)}$

電解脱珠法による脱珠水については両法の結果がよ く一致したので，主として比色法によつた。

(2) 理酸の測定法

Dienert-Wandenbulk 改良法 ${ }^{(11)}$ 飞よつた.

\section{4. 水酸化アルミニウム製造条件の検討}

（1）電解夜の $\mathrm{pH}$ と溶存アル そとの関係（静止法） 電解開始後数 $\min$ 経過すると水酸化アルミの絮状 渡激を生じるが，その一部分はアルミン酸となり溶解 するものと推定される. 電解液を静置, 沈降後腹過乙 て, 濾渡に溶存するアルミン酸を溶存 $\mathrm{A} 1$ として測 定した.

条件 直 流: $360 \mathrm{~mA}$

交 流： $40 \mathrm{~mA}$

電解液： $500 \mathrm{cc}$ (分幡上水 $\mathrm{pH} 7.2$ )

結果

\begin{tabular}{|c|c|c|}
\hline $\begin{array}{c}\text { 電 解 時 } \\
\text { (min) }\end{array}$ & 電解液の pH & $\begin{array}{l}\text { 溶存 } ル \text { ル } \\
(\mathrm{ppm}) ※\end{array}$ \\
\hline $\begin{array}{r}0 \\
2 \\
5 \\
15 \\
30 \\
60 \\
120\end{array}$ & $\begin{array}{l}7.2 \\
7.6 \\
7.8 \\
8.1 \\
8.7 \\
8.8 \\
8.9\end{array}$ & $\begin{array}{l}\mathrm{Tr} \\
1.0 \\
0.9 \\
0.85 \\
7.5 \\
9.0 \\
9.0\end{array}$ \\
\hline
\end{tabular}


水酸化アルミを用いた脱珪に最適とされている電解液 の $\mathrm{pH} 8.1$ である゙(14). pH 值がこれより高くなると生 成した水酸化アルミニウムがアルミン酸として溶解して
来るから pH 值が 8.2 以上となることを避ける必要があ る電解脱理法に於ては pH $8.0 \pm 0.2$ が最適域と考学る。

（2）電流密度及交直流比の影響（静止法）

\begin{tabular}{|c|c|c|c|c|c|c|c|c|c|}
\hline (A.C) D.C ) & $\begin{array}{l}\text { 電流密度 } \\
\left(\mathrm{mA} / \mathrm{cm}^{2}\right)\end{array}$ & $\begin{array}{r}\mathrm{D} \\
\mathrm{mA}\end{array}$ & (V) & $\begin{array}{r}\mathrm{A} \\
\mathrm{mA}\end{array}$ & (V) & $\begin{array}{l}\text { 電解時間 } \\
\text { (h) }\end{array}$ & $\begin{array}{l}\text { 瑏出 } \vec{\gamma} \\
(\mathrm{ppm} / \mathrm{Ah})\end{array}$ & $\mathrm{pH}$ & 備 \\
\hline $2 / 5$ & 1.75 & 50 & 5.5 & 20 & 15 & 2 & 335 & - & \multirow{3}{*}{$\begin{array}{l}\text { 極板面積 } \\
80 \times 50 \mathrm{~mm}\end{array}$} \\
\hline $1 / 5$ & 3.0 & 100 & 12.0 & 20 & 15 & 1 & 410 & - & \\
\hline $1 / 20$ & 10.5 & 400 & 26.0 & 20 & 15 & $1 / 4$ & 414 & - & \\
\hline 1/ 9 & 1.0 & 90 & 6 & 10 & 12 & 1 & 378 & 7.9 & \multirow[b]{2}{*}{ 極板面積 } \\
\hline $1 / 9$ & 3.0 & 270 & 13 & 30 & 36 & $1 / 3$ & 400 & 8.1 & \\
\hline 1/ 9 & 4.0 & 360 & 17 & 40 & 51 & $1 / 4$ & 410 & 8.1 & \multirow[t]{2}{*}{$85 \times 120 \mathrm{~mm}$} \\
\hline $1 / 19$ & 10.0 & 950 & 42 & 50 & 62 & $1 / 10$ & 388 & 7.8 & \\
\hline
\end{tabular}

交流の重畳割合が多くなると水酸化アルミの生成は減 少する傾向を諮めたが，交流と直流とのアルミニウム溶 出効果に対する正確な関係は求められなかつた. 実駼結 果加電流密度 $1.0 \sim 10 \mathrm{~mA} / \mathrm{cm}^{2}$, A.C./D.C. $=1 / 5 \sim 1 / 20$ の間に於てね殆えど一様な $\mathrm{A} 1$ 溶出が見られることを知 ๖.

\section{（3）電流濃度の影響（静止法）}

条件直 流: $360 \mathrm{~mA}$

交 流： $40 \mathrm{~mA}$

電解時間： $15 \mathrm{~min}$

電 解 液: $1.0 \sim 13.3 l$ 公幡上水

結果

\begin{tabular}{|c|c|c|c|c|c|}
\hline \multirow{2}{*}{$\begin{array}{c}\text { 電流濃度 } \\
(\mathrm{mA} / l)\end{array}$} & \multirow{2}{*}{$\mid \begin{array}{c}\text { 電解液量 } \\
(l)\end{array}$} & \multicolumn{2}{|c|}{$\begin{array}{l}\text { 了小溶出量 } \\
\text { 溶 }\end{array}$} & \multirow{2}{*}{ 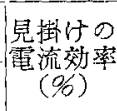 } & \multirow{2}{*}{$\begin{array}{c}\text { 䨝解後の } \\
\mathrm{pH}\end{array}$} \\
\hline & & (mg) & $(\mathrm{mg} / \mathrm{Ah})$ & & \\
\hline 400 & 1 & 82 & 408 & 122 & 8.1 \\
\hline 200 & 2 & 81.5 & 407 & 121.5 & 7.7 \\
\hline 133 & 3 & 78 & 389 & 116 & 7.7 \\
\hline 100 & 4 & 77 & 385 & 115 & 7.5 \\
\hline 30 & 13.3 & 75.5 & 375 & 112 & 7.4 \\
\hline
\end{tabular}

見掛けの電流效率が 100\%を越すこそは一罗不可解であ

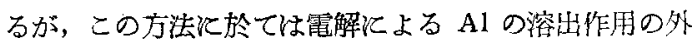
そ，電解液のアルカリ度の高石つれて見掛けの電流 效率の高末る点より考察して，化学的変化による溶出が 同時進行していると判断される。従つて電流濃度の 影響と $\mathrm{pH}$ の影響とを分離して考光ることは出来ない。

（4）電解の継続による $\mathrm{Al}$ 溶出量変化の有無（静止 法)

条件 直 流: $360 \mathrm{~mA}$

交 流: $40 \mathrm{~mA}$

電解液 : $500 \mathrm{cc}$ (八幡上水)

\begin{tabular}{|c|c|c|c|c|}
\hline \multirow{2}{*}{$\begin{array}{c}\text { 電解時間 } \\
(\mathrm{h})\end{array}$} & \multicolumn{2}{|c|}{ 溶出アルそ量 } & \multirow{2}{*}{$\begin{array}{c}\text { 見挂け口 } \\
\text { 電流效率 } \\
(\%)\end{array}$} & \multirow{2}{*}{$\mathrm{pH}$} \\
\hline & $(\mathrm{mg})$ & $(\mathrm{mg} / \mathrm{Ah})$ & & \\
\hline $1 / 4$ & 82 & 410 & 122.4 & 8.1 \\
\hline $1 / 2$ & 167 & 415 & 124.0 & 8.7 \\
\hline 1 & 336 & 420 & 125.4 & 8.8 \\
\hline 2 & 680 & 425 & 126.8 & 8.9 \\
\hline
\end{tabular}

電解を継続しても見掛けの電流効率には殆んど美異を

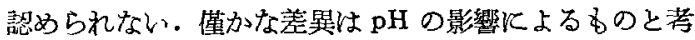
党られる。

（5）水酸化アル々製造装置の考察

両端極の間隔を一定にして，中間に電極を葆干枚择入 して電解を行う場合には，中間の極は複極として作用す

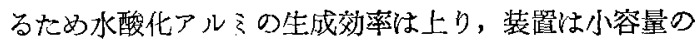
るので齐み，動力費の点からす極めて有利となり，この 装置によつて初めて本法経済的飞成立するるのとなる 5 .

效率的な水酸化アルミの生成法（流動法）

\begin{tabular}{|c|c|c|c|}
\hline $\begin{array}{l}\text { 電解槽の容量 } \\
\text { 電 極 面 積 } \\
\text { 雨端極の間隔 } \\
\text { 䡶入電極数 }\end{array}$ & $\begin{array}{l}1.6 l(90 \times 95 \times 1 \\
85 \times 180 \mathrm{~mm} \\
80 \mathrm{~mm} \\
0 \sim 8 \text { 林 }\end{array}$ & $90 \mathrm{~mm})$ & \\
\hline $\mathrm{E} \times \mathrm{P}-\mathrm{No}$. & 1 & 2 & 3 \\
\hline $\begin{array}{l}\text { D.C. } \\
\quad(\mathrm{mA}) \\
(\mathrm{V})\end{array}$ & $\begin{array}{r}125 \\
22\end{array}$ & $\begin{array}{r}250 \\
40\end{array}$ & $\begin{array}{r}400 \\
65\end{array}$ \\
\hline 量 $(l / h)$ & 10 & 20 & 32 \\
\hline ※電流密度 $\left(\mathrm{mA} / \mathrm{cm}^{2}\right)$ & 1.0 & 1.95 & 3.1 \\
\hline ※電流濃度 $(\mathrm{mA} / l)$ & 12.5 & 12.5 & 12.5 \\
\hline 宦 力 $(\mathrm{VA} / l)$ & 0.43 & 0.58 & 0.86 \\
\hline$(\mathrm{mA})$ & 43 & 43 & 43 \\
\hline (V) & 36 & 36 & 36 \\
\hline
\end{tabular}




\begin{tabular}{c|r|r|r}
\hline 補助極 $(\mathbf{n})$ & 溶出アル ミ 量 Al p.p.m Al p.p.m Al p.p.m \\
\hline 0 & 6.2 & 5.8 & 6.2 \\
1 & 11.2 & 10.0 & 10.7 \\
2 & 13.8 & 14.2 & 13.5 \\
3 & 15.3 & 15.9 & 17.6 \\
4 & 21.1 & 21.2 & 22.8 \\
5 & 27.2 & 26.3 & 27.8 \\
8 & - & - & 38.6 \\
\hline
\end{tabular}

※值流電流のみより計算した

以上の結果によれば同一霄流濃度における電解では， 電流密度をこの実験の範囲で変化させても溶出アルミの 量に殆んどその差を認めない. 溶出アルミ量を決定する 因子は挿入した補助極の数によることを詔める。本実賖 では直流と交流の霞流比が一定でなから正確な計算は 出来ないが，Al 1 p.p.m の浱唇に溶出与るに必要な笔 力救めて見ると次表の様で，插入した補助極の数そ增 すとこ秃に比例して消費電力は減少する。

- Al 1 p.p.m を溶出する化要する電力 (VA)

\begin{tabular}{c|c|c|c}
\hline Exp. No. & 1 & 2 & 3 \\
\hline 補助 & & & \\
\hline 0 & 0.069 & 0.100 & 0.138 \\
1 & 0.036 & 0.058 & 0.080 \\
2 & 0.031 & 0.041 & 0.064 \\
3 & 0.028 & 0.036 & 0.049 \\
4 & 0.020 & 0.027 & 0.037 \\
5 & 0.016 & 0.022 & 0.031 \\
8 & - & - & 0.022 \\
\hline
\end{tabular}

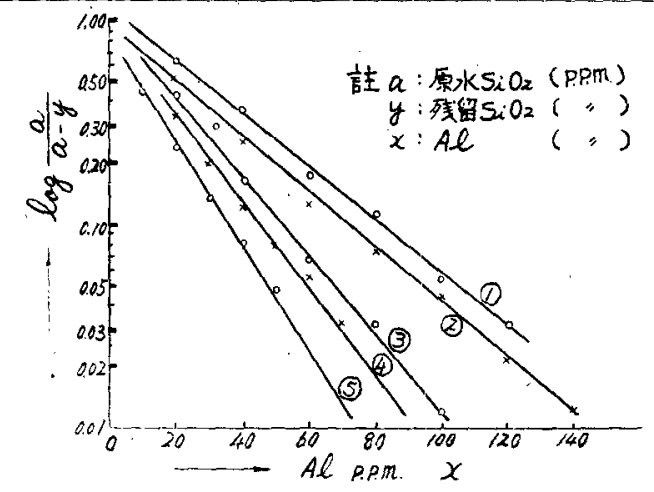

第 2 図 A1 所要量線图

\begin{tabular}{l|l|l} 
& 原水 $\mathrm{SiO}_{2}$ & $\log (\log a-y$ \\
\hline (1) & 65 p.p.m & $-0.013 x+0.047$ \\
(2) & $50 "$ & $-0.013 x-0.079$ \\
(3) & $42 "$ & $-0.019 x+0.005$ \\
(4) & $30 "$ & $-0.021 x-0.042$ \\
(5) & $23 "$ & $-0.026 x-0.092$ \\
\hline
\end{tabular}

\section{5. 眖珪条件の榆討（流動法）}

（1）西解法で調製した水酸化アルミの脱珪能 奏験装置

震 解 槽: $1.6 l(90 \times 95 \times 190 \mathrm{~mm})$

電椣面積 $: 8.0 \times 16.0=128\left(\mathrm{~cm}^{2}\right)$

補 的極: 8 枚

極間阿：条 $5 \mathrm{~mm}$

(a) 八幡上水の脱轨試験

拄酸含存量 : 17.5 p.p.m.

脱理目標: 5 6 p.p.m.

(中圧ボイラー用水として)

交流重量: $40 \mathrm{~mA}, 34 \mathrm{~V}$

嘚出アルミと残留珪酸との関係

\begin{tabular}{|c|c|c|c|}
\hline $\begin{array}{c}\text { 濡時間 } \\
\text { (min) }\end{array}$ & 1 & 3 & 4 \\
\hline$(l / h)^{\text {量 }}$ & 96 & 32 & 24 \\
\hline
\end{tabular}

\begin{tabular}{|c|c|c|c|c|c|c|c|}
\hline$\left(\begin{array}{r}\mathrm{D} \\
(\mathrm{mA})\end{array}\right.$ & V) & $\left|\begin{array}{r}\text { 浴 出 } \\
\text { ア ル } \\
\text { (p.p. } \\
\text { m.) }\end{array}\right|$ & $\begin{array}{l}\text { 榴 } \\
\text { 留 } \\
\text { (p.p. } \\
\text { m.) } \\
\text { m.) }\end{array}$ & 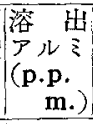 & $\begin{array}{l}\text { 残 留 } \\
\text { 酸 } \\
\text { (p.p. } \\
\text { m. })\end{array}$ & 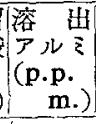 & $\begin{array}{r}\text { (b.p. } \\
\text { m }\end{array}$ \\
\hline & & . & 5.1 & - & - & -- & \\
\hline & & $\ldots$ & & 19.4 & 4.6 & - & \\
\hline & & - & - & 13.6 & 5.5 & - & \\
\hline & & - & 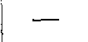 & - & - & 16.5 & 4.8 \\
\hline 年 & & - & 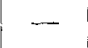 & $\ldots$ & - & 13.9 & 5. \\
\hline
\end{tabular}

(b) 京良城池水の眖珪

珪酸含有量: 17.9 p.p.m.

娟珪目棌: 5 6 p.p.m.

(中压ボイラー用水として)

1 p.p.m.

（高压ボイラー用水として）

交流重畳: $40 \mathrm{~mA}, 34 \mathrm{~V}$

塎出アルミと残留珪酸との関係

\begin{tabular}{|c|c|c|c|c|}
\hline $\begin{array}{c}\text { 湍 留 時 } \\
\text { (min) }\end{array}$ & \multicolumn{2}{|r|}{4} & \multicolumn{2}{|r|}{6} \\
\hline$(l h)^{\text {量 }}$ & \multicolumn{2}{|r|}{24} & \multicolumn{2}{|c|}{16} \\
\hline$\underset{(m A)}{\text { D.C. }}(\mathrm{V})$ & 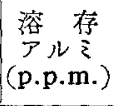 & $\begin{array}{l}\text { 残 留 } \\
\text { 珪 酸 } \\
\text { (p.p.m.) }\end{array}$ & $\begin{array}{l}\text { 溶 存 } \\
\text { ア } \\
\text { (p.p.m.) }\end{array}$ & $\begin{array}{c}\text { 残 留 } \\
\text { 恄: 煰 } \\
\text { (p.p.m.) }\end{array}$ \\
\hline 100 & 13.0 & 5.9 & - & - \\
\hline 200 & - & - & 41 & 0.85 \\
\hline
\end{tabular}

（c）珪酸含有量の変化と水酸化アルミ所要量さの 関係 八幡上水に化学用珠酸ソーダを添加して 
理酸含有量を調節し，これを脱珠するに必要な水 酸化アルミの量を測定した結果は第 2 図の様にな Dた.

(d) 脱珪の限界

脱珪に必要な水酸化アルミの量は，処理せんとす る水の珪酸含有量と処理後の残留珪酸の決定によ つて当然珙るが，可及的少量の水酸化アルミて日 標とする脱珪を行5ためには，水酸化アルえがそ の有する吸着能を十分炕発輝する様な使用方法を 構ずる心要がある.八憣上水を 0.1 p.p.m. まて 脱理する条件を求めると次表の様である。

\begin{tabular}{|c|c|c|c|c|c|}
\hline $\begin{array}{l}\text { D.C. } \\
(\mathrm{mA})\end{array}$ & $\begin{array}{l}\text { A.C. } \\
\text { (mA) }\end{array}$ & $\frac{{ }^{\text {流 }}(l / \mathrm{h})}{\text { 量 }}$ & $\begin{array}{c}\text { 溶 出 } \\
\text { アルミ } \\
\text { (p.p.m) }\end{array}$ & $\begin{array}{ll}\text { 残 } & \text { 留 } \\
\text { 理 } \\
\text { (p.p.m }\end{array}$ & 掅 掅 \\
\hline 500 & 20 & 6 & 480 & 0.07 & \multirow{3}{*}{ 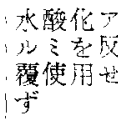 } \\
\hline 500 & 20 & 12 & 163 & 0.10 & \\
\hline 500 & 20 & 24 & 83.8 & 0.48 & \\
\hline 150 & 20 & 12 & 48.8 & 0.09 & \multirow{2}{*}{ 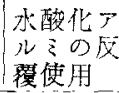 } \\
\hline 100 & 20 & 8 & 48.0 & 0.09 & \\
\hline
\end{tabular}

生成水酸化アルミの効率的な使用によつて水酸化アルミ の必要量は照減し，必要電力並びに電解槽容量子減少す る.

\section{(2) 㙂珪速度}

電解槽で生成した水酸化アルミを含さ水を電榑より流

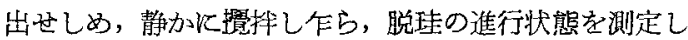
た結果は次表の通りである。

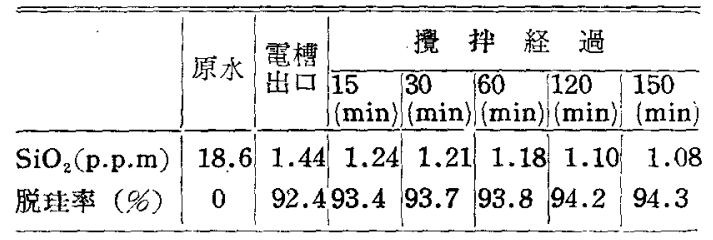

電槽滞留時間 (4 min) 内に大部分の脱理䅂了してい る.この状沅下の水酸化アルミによつては，この低い残 留珪酸濃度の水からの脱理の進行極めて除々である. 本法による脱珪速度は純化学的に調製した水酸化アルミ の脱珪速度に比較して摆か、大である。

（3）脱理水の水質

八憣上水，その脱珪水及び脱珪後イオン交换法で脱塩 乙た純水の水質を比輘すると次表の様である。(昭和 27 年 4 月 23 日午前 9 時の採水)

以上の結果電解脱珪法には脱珪以外飞除硬, 除濁, 除 鉄, コロイド状理酸の除去,塩類の減少等の副次的效果が 認められた．文他の奏験ては濁度 $25^{\circ}$ の池水は脱珪操作 Кよつて $5^{\circ}$ 以下の濁度とすることが出来た. 従つて電 解脱理法は脱珠法のみならず給水の前処理法としても極 めて適当な方法である。

\begin{tabular}{|c|c|c|c|c|c|}
\hline & 八㡖上水 & \multicolumn{2}{|c|}{ 脱琣水脱拄脱塩水 } \\
\hline$P$ & & 値 (cc) & 0.0 & 0.0 & 0.0 \\
\hline $\mathrm{m}$ & & 値 (cc) & 1.9 & 1.8 & 0.15 \\
\hline & $\mathrm{Cl}$ & $(\mathrm{mg} / l)$ & 14.0 & 12.8 & 0.0 \\
\hline$\hat{\mathrm{S}}$ & 硬 & 度 $\left({ }^{\circ} \mathrm{dH}\right)$ & 6.24 & 4.6 & 0.02 \\
\hline & 酸壏碽 & 度（" ” ) & 5.32 & 4.21 & 0.0 \\
\hline & 炭酸塩在 & 更度（" ”) & 0.91 . & 0.39 & 0.02 \\
\hline & $\mathrm{SO}_{3}$ & $(\mathrm{mg} / \mathrm{l})$ & 96 & 90 & 0.0 \\
\hline & $\mathrm{Fe}$ & $(")$ & 0.2 & 0.04 & 0.04 \\
\hline 全 & $\mathrm{SiO}_{2}$ & $(" \prime)$ & 19.2 & 1.26 & 1.23 \\
\hline & オン状S & $\mathrm{iO}_{2}(")$ & 15.3 & 1.0 & 1.0 \\
\hline & ロイド & $\mathrm{fSiO}_{2}(n)$ & 3.9 & 0.26 & 0.23 \\
\hline & $\mathrm{MgO}$ & $(")$ & 17.6 & 14.5 & 0.7 \\
\hline & $\mathrm{CaO}$ & $(n)$ & 37.6 & 25.8 & 1.0 \\
\hline 游: & 離堆 & 酸 ( " ") & 8.5 & 2.5 & 1.0 \\
\hline 蒸 & 発 残 & 活 $(" n)$ & 310 & 258 & 9.2 \\
\hline 妁 & 熱 残 & 活(" $)$ & 239 & 198 & 4.6 \\
\hline 灼 & 熱 減 & 量 (" & 71 & 60 & 4.6 \\
\hline & $\mathrm{pH}$ & & 7.3 & 29 & \\
\hline 比 & 抵 & 抗 $(Q-\mathrm{cm})$ & 2.900 & $2.900<$ & $70.000<$ \\
\hline
\end{tabular}

（4）電解法で調製した水酸化アルミと水酸化鉄の脱 理能比較

笔掼として鉄板を用い浴出する水酸化鉄を以て脱理 した場合と，従来の水酸化アルミを以て脱珒した場合

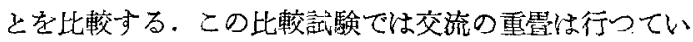
ない。

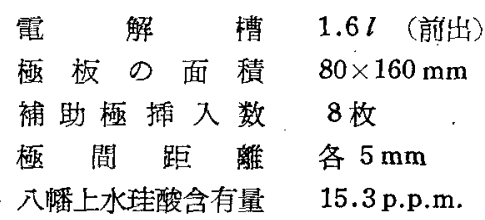

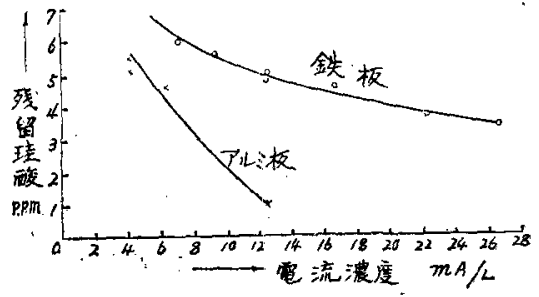

第 3 図水酸化鉄々水酸化アルミニウムの 肪珪能比較

$1 l$ の八膰上水を脱珪するに要する 鉄板，アルミ板の重量比較 (mg)

\begin{tabular}{l|c|cc}
\hline 脱 理目標 & Al & 板 & Fe \\
\hline 1 p.p.m 以下 & $42 \sim 45$ & 板 \\
3 4 p.p.m & $20 \sim 25$ & 難 \\
5 6 p.p.m & $13 \sim 15$ & $80 \sim 200$ \\
\hline
\end{tabular}


電解的に製造した水酸化鉄によつては 3 p.p.m. 绅下 飞脱珪することは困難である，又経済的にす水酸化アル ミニウムを使用した場合汇較べ有利性は認められない。

\section{6. 工業化試験の概要}

(1) 試験計画の概要

既述した試験結果によつて工業化試験を計画した．計 画の概要は次表の通りである。

\begin{tabular}{|c|c|c|}
\hline & 中匡ボイラー用 & 高圧ボイラー用 \\
\hline 脱 琟 $\begin{array}{c}\text { 目 標 } \\
\text { (p.p.m.) }\end{array}$ & $5 \sim 6$ & 1 \\
\hline $\begin{array}{r}\text { 原水理酸濃度 } \\
\text { (p.p.m.) }\end{array}$ & 18 & 18 \\
\hline 好 理 $\begin{array}{r}\text { 量 } \\
\left(\mathrm{m}^{3} / \mathrm{h}\right)\end{array}$ & 15 & 6 \\
\hline $\begin{array}{l}\text { 脱理に要する } \\
\mathrm{Al} \text { 量 } \quad(\mathrm{g} / \mathrm{h})\end{array}$ & 270 & 270 \\
\hline 電流 $(\mathrm{DC})(\mathrm{A})$ & 45 & 45 \\
\hline$(\mathrm{AC})(\mathrm{A})$ & 4.5 & 4.5 \\
\hline 電 & $\operatorname{mm}_{2,440 \times 1,220 \times 20}$ & $\underset{2,440 \times 1,220 \times 20}{\mathrm{~mm}}$ \\
\hline 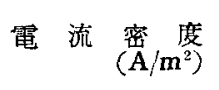 & 15.1 & 15.1 \\
\hline 電 解 $\left(\begin{array}{r}\text { 䄚 } \\
\text { (mm) }\end{array}\right.$ & $2,500 \times 1,250 \times 200$ & $2,500 \times 1,250 \times 200$ \\
\hline $\begin{array}{c}\text { 滞 留 時 間 } \\
(\mathrm{min})\end{array}$ & 2.5 & 6.25 \\
\hline
\end{tabular}

(2) 試験装置の概要

供試した試験装置の概要を図示すれば第 4 雪の様であ る。

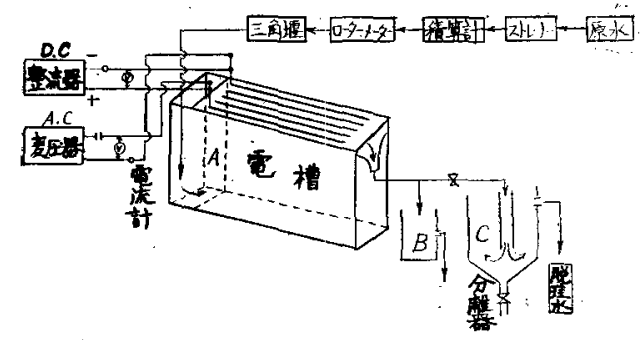

第 4 図 装置（概念四）

電 槽: 木製, コンタリート張り

$0.6 \mathrm{~m}^{3}(2,500 \times 1,250 \times 200 \mathrm{~mm})$

電極 : $99.7 \%$ アル板

$2,440 \times 1,220 \times 3.2 \mathrm{~mm}$ 羛板の睢使用

水銀整流器: A.C. $34,210 \sim 220 \mathrm{~V}, 50 \sim 60 \mathrm{~A}$,

D.C. $\quad 24 \sim 95 \mathrm{~V}, 50 \sim 100 \mathrm{~A}$,
交流配線：100 V $10 \mathrm{~A}$

コンデンサー : $220 \mu \mathrm{F}$

ローター・メーター: $6 \sim 9 \mathrm{~m}^{3} / \mathrm{h}$ 用, $12 \sim 15 \mathrm{~m}^{3} / \mathrm{h}$ 用

三角姮 : $800 \times 1,800 \times 500$

積算水量計 : $3^{\prime \prime} \phi$

(3) 陚験結果の概要

(a) 溶出アルミと残留珪酸との関係

珪酸含有量 $17 \sim 18$ p.p.m. の八幡上水を毎時 $6 \mathrm{~m}^{3}$ 流 し，電流を変化して脱珪の状況を試験した結果は第 5 図 の如く, 約 40 A で I p.p.m. まで脱理出来ることを確 認した。

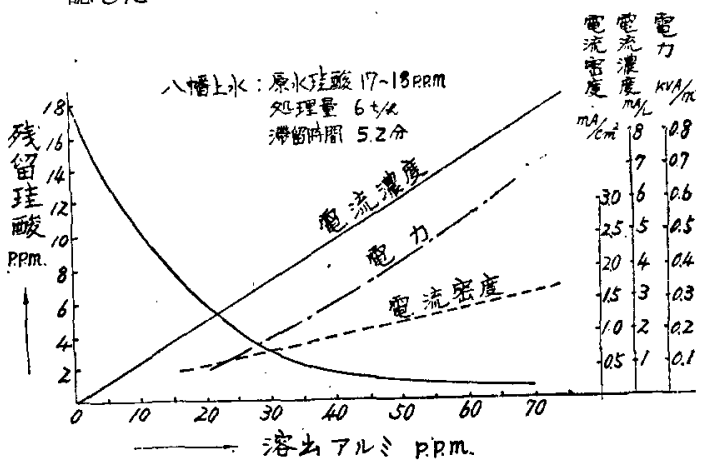

第 5 図残留珪酸と溶出アルミとの関係

（b）水質の変化による溶出アルミと残留珪酸との関 係の偏移

八憣上水中の珠酸含有量忤平均 $17 \sim 18$ p.p.m. 上限 20 p.p.m. 下限 8 9 p.p.m. を示す. 20 p.p.m.上上の水 を調製するためには珪酸ソーダを添加した．水筫の変化 による溶出アルミと残留珪酸との関係汢第 6 図の様であ る. 又水䨘の変化化よる本装置での処理可能量の增減は 第 7 図の樣である.

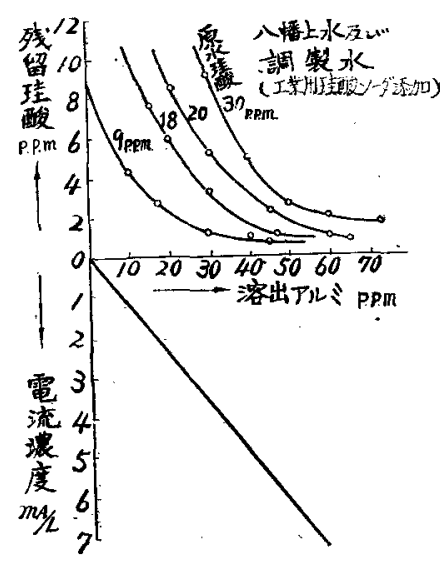

第 6 図 水質の変化による溶出アルミ と残留㯰酸との関係 


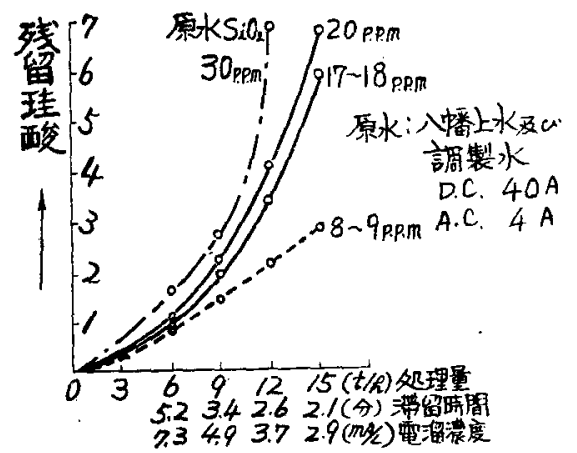

第 7 図 水質の変化による残留 战:酸と処理量との関保

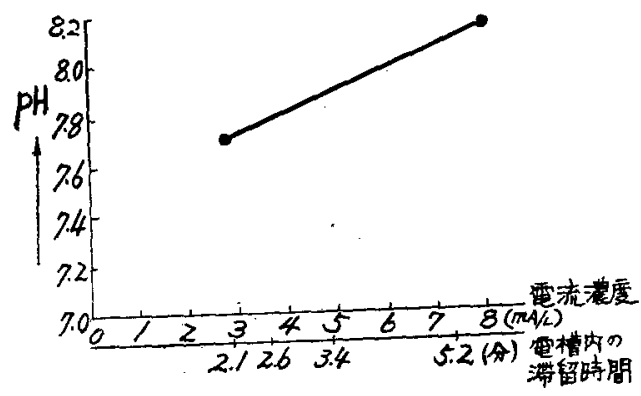

第 8 図 処理水 $0 \mathrm{pH}$ と電流濃度との関係

(c) 処理水の $\mathrm{pH}$ と霹流濃度との関係

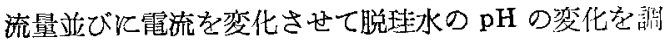
べた結果は第 8 図の様で，最適 $\mathrm{pH}$ 域である $8.0 \pm 0.2$ の䇺囲にあつた。

(d) 電流濃度と溶出アルミ量との関係

極板を 20 枚とした場合と 13 枚とした場合について試 験した結果，何え子直線的関係炕あつた（第 9 図参圤）。

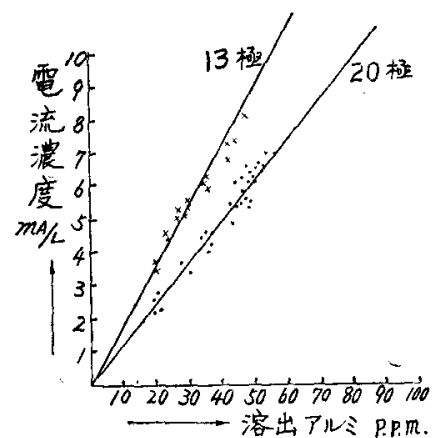

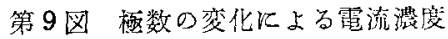
と溶出アルミの関係 （e）電極表面の状沅

電解を継続すること 20 日間にして電榑電圧の上早が 認められ初めたので，24日閐の運転の後電極を取出して 点検した結果陰極面に緻密な皮膜か附着しているのを認 めた．向隄極面に附着した沈搌物は蹯で容易に取除くこ とが出来たが，㓌極面の皮膜は除去に困難であつた．

これ等支偾を検討した結果抵抗増加の主な原因は㓌極面 の皮膜であつて，陽極面の皮膜の抵抗增加は小であるこ とを知つた.この皮膜の生成好止については间研究中で あるが，一旦生した皮膜をサンド・ブラストして再用す れげ新極と殆んど同様使用出来る.向この皮膜の除去 法として化学的な溶解法，電気的な方法，洌壳ば極生の 交替等行つたが，最す簢便で效果的な方法はサンド・ブ ラスト法であると認めている。

\section{7. 結}

㫪

電解脱珪法に注理的飞不明の点す多く，且つ装置， 留軽等についでも向改良を要する点も多いが, 本試験の 結果電解脱珪法が工業的成立し得るととを認めた。特 飞本法は脱塩を必要としない程度の中庄ボイラーで，除 硬と脱珪を必要とする給水の処理には適当な処理法であ ると考える。

本工業化試騒は胆和 26 年度鉣工業技術研究禣助金の 補助によつたもので，ここに感謝の意を表する。修本試 験に当り御指導を们いた北海道大学岡本教授, 香山教 授，大蔵助教授汇梁䓕の謝意を表する。

(昭 28-7-23 受理)

文 献

(1) Betz, Noll, Maguire : I. E.C., 32, $1326(1940) ; 33,814$ (1941)

(2) Baumann, Eichhorn, Wirth : ibid., 39, 1453 (1947)

(3) F.G. Straub : Ibid., 24, 1174 (1932)

(4) " : Ibid., 28, 113 (1936)

(5) V.J. Calise, M. Lane : Chem. Eng. Progr., 44, 269 (1947).

(6) 山村利夫：日本化学会九州支部常会 (昭 24,6 月)

(7) Splittgerber : Chem. Tabrik., 13, (1940)

(8) Arch. Wärmewirtsch. Dampfkesselwes, 19, 324 (1938)

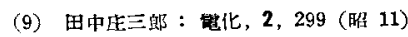

(10) W. D. Hatfield ; I.E.C.., 16, 233 (1924)

(11) 新海重行：工化，46，234（昭 18） 大藏武：日化，72，927（昭 26)

(12) 䀳本, 大蔵：化学上工策, 4，98(昭 26)

(13) Power, 94, June (1952)

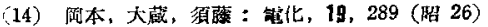

